\title{
Optimization of the Lipase Catalyzed Production of Structured Acylglycerols With Polyunsaturated Fatty Acids Isolated From Sardine Oil
}

\author{
Juan Antonio Noriega-Rodríguez ${ }^{1}$, Esther Carrillo-Perez ${ }^{1}$, Nohemí Gámez-Meza ${ }^{2}$, Luis A. Medina-Juárez ${ }^{2}$, \\ Ramiro Baeza-Jiménez ${ }^{3}$ \& Hugo S. García ${ }^{4}$ \\ ${ }^{1}$ Departamento de Ingeniería Química y Metalurgia, Universidad de Sonora, Hermosillo Sonora, México \\ ${ }^{2}$ Departamento de Investigaciones Científicas y Tecnológicas, Universidad de Sonora, Hermosillo Sonora, \\ México \\ ${ }^{3}$ Centro Conjunto de Investigación en Química Sustentable. Universidad Autónoma del Estado de México. \\ Toluca, Estado de México, México \\ ${ }^{4}$ Unidad de Investigación y Desarrollo en Alimentos, Instituto Tecnológico de Veracruz, Veracruz México \\ Correspondence: Juan Antonio Noriega-Rodríguez, Departamento de Ingeniería Química y Metalurgia, \\ Universidad de Sonora, Hermosillo Sonora, México. Tel: 52-662-259-2106. E-mail: \\ janoriega@guayacan.uson.mx
}

Received: August 26, 2013 Accepted: October 30, 2013 Online Published: November 19, 2013

doi:10.5539/jfr.v2n6p97 URL: http://dx.doi.org/10.5539/jfr.v2n6p97

\begin{abstract}
In the present work, direct enzyme-catalyzed esterification of n-3 polyunsaturated fatty acids (n-3 PUFA) isolated from sardine oil was optimized to obtain structured acyglycerols. A n-3 PUFA concentrate was prepared by urea crystallization of refined sardine oil and esterification was carried out mixing free fatty acids and glycerol at different molar ratios $(M=0.48,1.5,3.0,4.5$ and $5.52 \mathrm{~mol} / \mathrm{mol})$, using an immobilized lipase preparation from Candida antarctica (NV-435) at different temperatures $\left(T=38,45,55,65\right.$ and $\left.72{ }^{\circ} \mathrm{C}\right)$ and reaction times $(t=0.7,2.75,5.75,8.75$ and $10.8 \mathrm{~h})$ in a rotatable central composition design. The degree of esterification was determined by analysis of the acylglycerides produced, using liquid chromatography (HPLC-ELSD). Optimization by response surface methodology (RSM) showed that in order to obtain higher esterification levels of n-3 PUFA to glycerol (99.5\%), a molar ratio of 1.3 mol n-3 PUFA/mol glycerol, time 8.3 $\mathrm{h}$ and temperature $38{ }^{\circ} \mathrm{C}$, are required. However, results of this work show that it is possible to drive the reaction to any determined product (MAG, DAG or TAG) by modifying the reaction conditions.
\end{abstract}

Keywords: acylglycerides, enzymatic esterification, polyunsaturated fatty acids, response surface methodology, sardine oil, hplc-elsd

\section{Introduction}

N-3 polyunsaturated fatty acids (n-3 PUFA) are essential fatty acids because they cannot be synthesized by humans and animals; their tissues lack the enzymatic mechanism to insert double bonds before carbon nine from the end methyl group (Makrides, Neumann, \& Gibson, 1996). The well documented health beneficial effects of n-3 PUFA for cardiovascular disease, rheumatoid arthritis, immune function and cancer (Mantzioris, Cleland, \& Gibson, 2000; Li, Bode, Drummond, \& Sinclair, 2003; Cleland, Caughey, James, \& Proudman, 2006) have promoted the rapid development of the nutraceutical and pharmaceutical markets (Young, 2003). One of the most important effects of eicosapentaenoic (EPA) and docosahexaenoic (DHA) acids is the prevention of arrhythmias (Sellmayer \& Koletzco, 1999); furthermore, researchers have concluded that n-3 PUFA can reduce the amount of triacylglycerides (TAG) in 25 and 30\%, with a dose of 2 and $3 \mathrm{~g}$ /day (Harris \& Isley, 2001).

Fish oil is well known for its high content of n-3 fatty acids (FA), with documented benefits on human health (Nettleton, 1994). DHA has proven capable to reduce the risk of heart disease and inflammatory cytokines (Simopoulos, 2002; Von Schacky, 2007). Additionally, DHA inhibits tumour cells growth (Zhang, Long, Zhang, \& Wang, 2007) and it can be consumed as acylglycerol for its moderate absorption and less oxidation compared to the free fatty acid form (Valenzuela, Valenzuela, Sanhueza, \& Nieto, 2005). Different methods have been 
developed to obtain n-3 PUFA extracts (as acylglicerides or free fatty acids) from marine oils; some of those methods have been combined to increase both efficiency and yield of the extraction (Gamez, Noriega, Medina, Ortega, García, \& Angulo, 2003). n-3 PUFA are easily oxidized, for that reason enzymatic reactions have been studied for the production of oils with elevated content of n-3 PUFA, because these reactions are conducted in mild conditions (Haraldsson, Kristinsson, Sigurdardottir, Gudmundsson, \& Breivik, 1997). The enzyme-catalyzed enrichment of fish oil with n-3 PUFA have been carried out via transesterification, direct esterification of glycerol with EPA and DHA, interesterification of tributyrin with ethyl esters of EPA and DHA (Haraldsson, Gudmundson, \& Almarsson, 1995) and the direct esterification of the free fatty acid (FFA) from tuna oil with alcohols (Shimada, Sugihara, Nakano, Kuramoto, Nagao, Gemba, \& Tominaga, 1997). The aim of the present work was the optimization, employing response surface methodology (RSM), of the enzyme-catalyzed esterification of the n-3 PUFA isolated from sardine oil.

\section{Methods}

To carry out the enzyme-catalyzed esterification, glycerol (reagent, J. T. Baker), molecular sieves (Sigma, 1.6 $\mathrm{mm}$ and $4 \AA$ ), tert-butylhydroxiquinone (TBHQ, Química Dresen) as antioxidant and nitrogen (ultra high purity, 99.999\%), were employed. The commercial immobilized Novozym 435 (Novo Nordisk, Bagsbaerd, Dennmark) from Candida antarctica fraction B was employed as the biocatalyst. All the solvents for analysis were HPLC-grade (Fisher, Sigma-Aldrich), and they were filtered $(0.45 \mu \mathrm{m})$ and degassed before their use. The standards used were trilinolein (C99\%), 1,2 dipalmitin (C99\%), 1,3 diolein (C99\%), 1-monoolein (C99\%) and heptadecanoic acid (C99\%) that were purchased from Sigma-Aldrich (Mexico).

\subsection{Concentrate Extracts of $n-3$ PUFA}

Fresh crude oil from whole sardine (Sardinops sagax caeruleus) was obtained from a fishmeal plant located at Guaymas, Mexico. Refining (R), bleaching (B), and deodorizing (D) of the sardine oil was carried out according to recommended procedures for fish oil (Noriega, Ortega, Angulo, García, Medina, \& Gámez, 2009). To obtain the n-3 PUFA from RBD sardine oil, we followed the method described by Gamez, Noriega, Medina, Ortega, García and Angulo (2003). ca. $100 \mathrm{~g}$ of RBD sardine oil (containing $0.02 \mathrm{~g}$ of TBHQ) were saponified with 200 $\mathrm{mL} 7 \mathrm{M} \mathrm{KOH}$ in ethanol $(70 \%)$ under reflux at $90{ }^{\circ} \mathrm{C}$ for $1 \mathrm{~h}$. The saponifiable fraction was extracted with distilled water $(240 \mathrm{~mL})$ while the unsaponifiable material was extracted with hexane $(200 \mathrm{~mL})$ and discarded. The aqueous layer containing the saponified matter was acidified to $\mathrm{pH}=1.0$ with $3 \mathrm{~N} \mathrm{HCl}$, for the extraction of FFA with hexane $\left(200 \mathrm{~mL}\right.$, twice), which was further evaporated in a rotary evaporator at $40{ }^{\circ} \mathrm{C}$ and $25 \mathrm{~mm} \mathrm{Hg}$. Anhydrous $\mathrm{Na}_{2} \mathrm{SO}_{4}$ was added to dry the concentrate extracts. ca. $15 \mathrm{~g}$ of the obtained FFA were placed in Erlenmeyer flasks with urea $(25 \mathrm{~g})$ and ethanol $(95 \%, 100 \mathrm{~mL})$ to be heated and stirred until the whole mixture turned into a clear homogeneous solution. The mixture was transferred to centrifugue tubes and rapidly cooled by immersion in cold water, then kept refrigerated $\left(4^{\circ} \mathrm{C}, 8 \mathrm{~h}\right)$. Crystals were removed by centrifugation $(6000 \mathrm{xg})$ for $20 \mathrm{~min}$ at $5{ }^{\circ} \mathrm{C}$. The supernatant was kept at $-30^{\circ} \mathrm{C}$ for $12 \mathrm{~h}$ then centrifuged again $(6000 \mathrm{xg})$ at $-30{ }^{\circ} \mathrm{C}$ for 20 min. Non-complexing supernatant (containing the PUFA) was acidified at $\mathrm{pH} 4.0$ and equal volumes of warm $\left(65^{\circ} \mathrm{C}\right.$ ) water and hexane were added and stirred thoroughly for $30 \mathrm{~min}$. The n-3 PUFA concentrate was obtained after separation of the phases and evaporation of the solvent $\left(40 \mathrm{rpm}, 40^{\circ} \mathrm{C}, 25 \mathrm{mmHg}\right)$.

\subsection{Analysis of Fatty Acids}

FFA were transformed into the corresponding methyl esters with $12 \%$ borontrifluoride in methanol (Ce 2-66 AOCS, 2009). A Varian 3400 gas chromatograph, equipped with a flame-ionization detector analyzed the composition of FFA. The column used was Omegawax $250(30 \mathrm{~m} \times 0.25 \mathrm{~mm}$ i.d., $0.25 \mathrm{~mm}$ film thickness; Supelco, Inc., Bellefonte, PA). The oven temperature was held at $205^{\circ} \mathrm{C}$ for $5 \mathrm{~min}$, then increased to $240{ }^{\circ} \mathrm{C}$ at $4{ }^{\circ} \mathrm{C} / \mathrm{min}$ and held at $240{ }^{\circ} \mathrm{C}$ for $8 \mathrm{~min}$. The injector and flame ionization detector were held at 250 and $260{ }^{\circ} \mathrm{C}$, respectively. Nitrogen was used as carrier gas at $20 \mathrm{~cm} / \mathrm{s}$ flow rate. Identification of the fatty acids was based on a menhaden oil fish standard obtained from Supelco (4-7116). Heptadecanoic acid (C17:0) was used as internal standard.

\subsection{Enzyme-Catalyzed Esterification}

For all of the esterification reaction trials, different temperatures $\left(\mathrm{T}=38,45,55,65\right.$ and $\left.72{ }^{\circ} \mathrm{C}\right)$, substrates molar ratios $(\mathrm{M}=0.48,1.5,3.0,4.5$ and 5.52 FFA:glycerol $)$ and reaction times $(\mathrm{t}=0.7,2.75,5.75,8.75$ and $10.8 \mathrm{~h})$ were employed, according to a rotatable central composition design (Montgomery, 2009). $1.0 \mathrm{~g}$ of the substrates mixture (containing $0.02 \% \mathrm{w} / \mathrm{w}$ of TBHQ and molecular sieves $20 \% \mathrm{w} / \mathrm{w}$ of substrates) was mixed in a $10 \mathrm{~mL}$ glass vials and placed into an incubator with continuous shaking $(220 \mathrm{rpm})$ at constant temperature. To start the reaction, $50 \mathrm{mg}$ of lipase were added. The vials were flushed with nitrogen, sealed with rubber caps and parafilm, and continuously shaken for the trial time. 


\subsection{Analysis of Acylglicerols}

Samples were withdrawn $(10 \mu \mathrm{L})$ and dissolved with $5 \mathrm{~mL}$ of solvent extractor $\mathrm{CHCl}_{3}: \mathrm{CH}_{3} \mathrm{OH}(2: 1)$. Alicuots (1 $\mathrm{mL}$ ) of this mixture were transferred to $13 \times 100$ tubes for solvent evaporation by flushing nitrogen. The remaining matter was redissolved in $1 \mathrm{~mL}$ hexane:2-propanol (90:10) to be analyzed by HPLC as reported previously (Liu, Lee, Bobik, Guzman, \& Hastilow, 1993). The analysis was carried out using a Varian 9012 HPLC system, fitted with an ELSD 500 (Evaporative Light Scatering Detector; Alltech) using Nitrogen as nebulizer gas at $2.1 \mathrm{bar}$, and the drift tube temperature was set at $90{ }^{\circ} \mathrm{C}$. The analytical column $(250 \mathrm{~mm} \times 4.6$ $\mathrm{mm}$ ID x $5 \mu \mathrm{m}$ ) was a Lichrosorb Si60 (Supelco). A loop of $10 \mu \mathrm{L}$ was employed to inject of samples into the column. The chromatographic separation was carried out at $40^{\circ} \mathrm{C}$ using a jacket (Alltech) connected to a recirculation water bath (Thermomix 1420; B. Braun).

\subsection{Experimental Design and Statistical Analysis}

Experiments were conducted using a central composite design to investigate the linear, quadratic, and cross-product effects of three factors, each varied at five levels and also included four central points for replicates. The three factors chosen were substrates molar ratio $\left(\mathrm{x}_{1}=0.48,1.5,3.0,4.5\right.$ and $\left.5.52 \mathrm{FFA} / \mathrm{glycerol}\right)$, reaction time $\left(\mathrm{x}_{2}=0.7,2.75,5.75,8.75\right.$ and $\left.10.8 \mathrm{~h}\right)$ and reaction temperature $\left(\mathrm{x}_{3}=38,45,55,65\right.$ and $\left.72{ }^{\circ} \mathrm{C}\right)$ for the global esterification $\left(y_{1}\right)$ and the production of monoacylglycerols $\left(y_{2}\right)$, diacylglycerols $\left(y_{3}\right)$ and triacylglycerols $\left(y_{4}\right)$.

The design of the experiments employed is depicted in Table 2. To predict the dependent variables $\left(y_{i}\right)$ a polynomial regression of a second-order model was assumed as follow:

$$
y=\beta_{0}+\sum_{i=1}^{k} \beta_{i} x_{i}+\sum_{i=1}^{k} \beta_{i i} x_{i}^{2}+\sum_{i<j} \sum \beta_{i j} x_{i} x_{j}+\varepsilon
$$

where: $\beta o, \beta i, \beta i i$ and $\beta i j$, represent the coefficients for combined, lineal, quadratic and interaction effects of the regression, respectively. In order to screen the effect of independent variables and to further determine the optimal conditions for the enzyme-catalyzed esterification, analysis of variance and RSM were performed respectively, with the statistical program JMPin 4.0.4 (SAS Institute, Inc.).

Table 1. Composition of sardine oil andconcentrated extract of n-3 PUFA (wt\%)*

\begin{tabular}{lll}
\hline Fatty Acid & Sardine Oil & n-3 PUFA Concentrate \\
\hline C14:0 & 5.65 & -- \\
C16:0 & 17.07 & -- \\
C16:1 & 5.71 & 7.87 \\
C18:0 & 4.19 & 0.29 \\
C18:1 & 9.15 & 6.82 \\
C18:2 n-6 & 1.34 & -- \\
C18:3 n-3 & 0.18 & -- \\
C18:4 n-3 & 1.57 & 10.42 \\
C20:1 & 2.97 & -- \\
C22:1 & 1.18 & -- \\
C20:5 n-3 & 8.64 & 18.21 \\
C22:5 n-3 & 0.50 & -- \\
C22:6 n-3 & 10.16 & 52.80 \\
In-3 PUFA & 21.01 & 81.43 \\
\hline
\end{tabular}

*Total do not add to $100 \%$ because some minor peaks of the chromatogram were not identified or concentration was below $0.1 \%$. 
Table 2. Experimental setup for enzyme-catalyzed esterification of n-3 PUFA of sardine oil

\begin{tabular}{|c|c|c|c|c|c|c|c|}
\hline \multirow{2}{*}{ Experiment } & \multicolumn{3}{|c|}{ Variables } & \multicolumn{4}{|c|}{ Responses } \\
\hline & $\mathrm{x}_{1}$ & $\mathbf{x}_{2}$ & $\mathbf{x}_{3}$ & $y_{1}$ & $y_{2}$ & $y_{3}$ & $y_{4}$ \\
\hline 1 & 1.5 & 2.75 & 45 & 81.8 & 52.0 & 23.4 & 6.5 \\
\hline 2 & 1.5 & 2.75 & 65 & 80.3 & 40.2 & 33.4 & 6.7 \\
\hline 3 & 1.5 & 8.75 & 45 & 93.0 & 50.0 & 26.7 & 16.3 \\
\hline 4 & 1.5 & 8.75 & 65 & 71.6 & 33.4 & 23.6 & 14.6 \\
\hline 5 & 4.5 & 2.75 & 45 & 75.8 & 58.2 & 12.4 & 5.2 \\
\hline 6 & 4.5 & 2.75 & 65 & 60.4 & 34.5 & 14.8 & 11.0 \\
\hline 7 & 4.5 & 8.75 & 45 & 68.6 & 33.2 & 8.8 & 26.5 \\
\hline 8 & 4.5 & 8.75 & 65 & 66.1 & 18.8 & 8.0 & 39.4 \\
\hline 9 & 0.48 & 5.75 & 55 & 90.7 & 41.0 & 35.3 & 14.4 \\
\hline 10 & 5.52 & 5.75 & 55 & 58.0 & 34.0 & 7.2 & 16.9 \\
\hline 11 & 3.0 & 0.7 & 55 & 25.4 & 17.8 & 4.9 & 2.7 \\
\hline 12 & 3.0 & 10.8 & 55 & 73.9 & 31.3 & 16.4 & 26.2 \\
\hline 13 & 3.0 & 5.75 & 38 & 72.2 & 43.3 & 26.2 & 2.7 \\
\hline 14 & 3.0 & 5.75 & 72 & 78.4 & 32.7 & 20.1 & 25.6 \\
\hline 15 & 3.0 & 5.75 & 55 & 70.4 & 35.6 & 25.3 & 9.6 \\
\hline 16 & 3.0 & 5.75 & 55 & 73.6 & 33.4 & 26.9 & 13.4 \\
\hline 17 & 3.0 & 5.75 & 55 & 66.0 & 31.4 & 23.3 & 11.3 \\
\hline 18 & 3.0 & 5.75 & 55 & 66.2 & 37.4 & 18.1 & 10.7 \\
\hline
\end{tabular}

$x_{1}=$ substrate molar ratio (FFA/glycerol), $x_{2}=$ reaction time $(\mathrm{h}), x_{3}=$ temperature $\left({ }^{\circ} \mathrm{C}\right), y_{1}=$ global esterification $(\%)$, $y_{2}=$ monoacylglycerols $(\%), y_{3}=$ diacylglycerols $(\%), y_{4}=$ triacylglycerols $(\%)$.

\section{Results \& Discussion}

The concentrate of FFA contained $81.43 \%(w / w)$ of $n-3$ PUFA, and consisted of $52.8 \%$ DHA, $18.2 \%$ EPA and $10.4 \%$ octadecatetraenoic acid (Table 1). The remaining matter was composed by monounsaturated fatty acids, mainly oleic (7\%). Table 2 lists the experimental parameter settings and the results based on the experimental design.

\subsection{Global Esterification (GE)}

The extent of esterification reached $93 \%$ for a $1.5 \mathrm{FFA} /$ glycerol substrates molar ratio, $8.75 \mathrm{~h}$ and $45{ }^{\circ} \mathrm{C}$ (Table 2). Esteban, Robles, Jiménez, Ibáñez \& Molina (1998), used a cod liver oil concentrate and obtained $68.5 \%$ of esterification after $48 \mathrm{~h}$ and for the following $48 \mathrm{~h}$, it only increased by $5.3 \%$. In other study, $92.5 \%$ of esterification was reported by Robles, Esteban, Giménez, Camacho, Ibáñez \& Molina (1999) after 24 h. The second order polynomial regression to experimental data generated the following model for esterification:

$$
y_{1}=205.7-16.2 \mathrm{x}_{1}+10.4 \mathrm{x}_{2}-4.9 \mathrm{x}_{3}+1.9 \mathrm{x}_{1}{ }^{2}+0.098 \mathrm{x}_{1} \mathrm{x}_{2}-0.45 \mathrm{x}_{2}{ }^{2}-0.02 \mathrm{x}_{1} \mathrm{x}_{3}-0.06 \mathrm{x}_{3} \mathrm{x}_{2}+0.04 \mathrm{x}_{3}{ }^{2}
$$

where $y_{1}$ is the extent of global esterification, $x_{l}$ the substrates molar ratio, $x_{2}$ the reaction time and $x_{3}$ the temperature.

Figure 1 shows the response surface generated for the experimental data of the global esterification. It can be observed that the greatest extent of global esterification could be obtained with the lower substrates molar ratio $(0.48 \mathrm{FFA} / \mathrm{glycerol})$ and temperature $\left(38^{\circ} \mathrm{C}\right)$, after $5 \mathrm{~h}$ of reaction. Low temperatures have been suggested for esterification of n-3 PUFA in order to prevent polymerization during the reaction (Kosugy \& Azuma, 1994). 

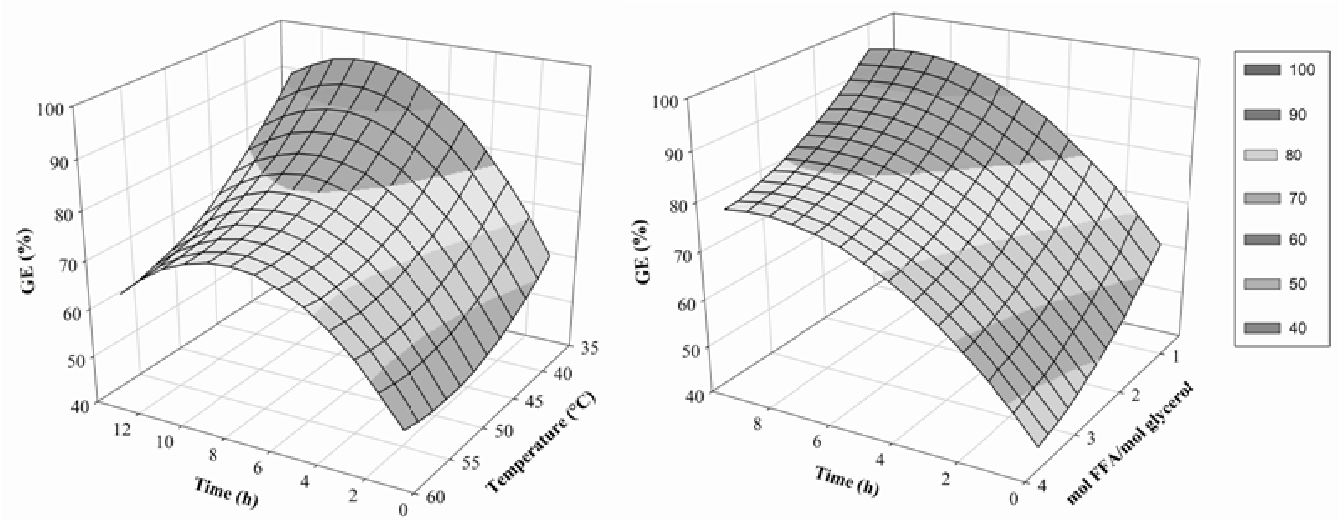

Figure 1. Response surface for global esterification of n-3 PUFA with glycerol

\subsection{Production of Triacylglycerols (TAG)}

Even when the higher global esterification obtained was 93\% (experiment 2), the production of TAG only reached 39\% (experiment 8), and this could be due the short reaction time employed $(8.75 \mathrm{~h})$ combined with substrate molar ratio (Table 2). Haraldsson, Gudmundson and Almarsson (1995), reported that more than $72 \mathrm{~h}$ are required for the production of TAG. Esteban, Robles, Jiménez, Ibáñez and Molina (1998), found that TAG formation can be increased from $26.4 \%$ to $59.4 \%$ using hexane. In the same work, these authors observed that when trials were allowed to react for $24 \mathrm{~h}$, a higher TAG formation was reached (55\%). Mc Neill, Ackman and Moore (1996), obtained more than $90 \%$ TAG production after $150 \mathrm{~h}$ of reaction. According to the ANOVA, our results shows that substrate molar ratio and the interaction of time with substrates molar ratio have a significant effect $(\mathrm{P}<0.05)$ on the TAG production. The resulted mathematical model for the production of TAG was:

$$
y_{2}=64.8-16.4 \mathrm{x}_{1}-2.6 \mathrm{x}_{2}-1.5 \mathrm{x}_{3}+0.81 \mathrm{x}_{1}{ }^{2}+0.93 \mathrm{x}_{1} \mathrm{x}_{2}+0.15 \mathrm{x}_{2}^{2}+0.15 \mathrm{x}_{1} \mathrm{x}_{3}+0.014 \mathrm{x}_{3} \mathrm{x}_{2}+0.012 \mathrm{x}_{3}^{2}
$$

where $y_{2}$ is the extent of TAG production, $x_{1}$ the substrates molar ratio, $x_{2}$ the reaction time and $x_{3}$ the temperature.

The statistical analysis shows that this model can estimate the experimental data with an $\mathrm{F}=0.0030$ and $\mathrm{R}^{2}=$ 0.9952, suggesting that variations could be explained by the fitted model. Figure 2 shows that for higher substrates molar ratio and reaction time, a higher TAG production is obtained. Some reports (Esteban, Robles, Jiménez, Ibáñez \& Molina, 1998; Haraldsson, Gudmundson, \& Almarsson, 1995) refer that $3 \mathrm{FFA} /$ glicerol is the optimal substrates molar ratio for TAG formation. However, Robles, Esteban, Giménez, Camacho, Ibáñez and Molina (1999), found that an increment of 50\% in glycerol concentration, TAG formation was increased.
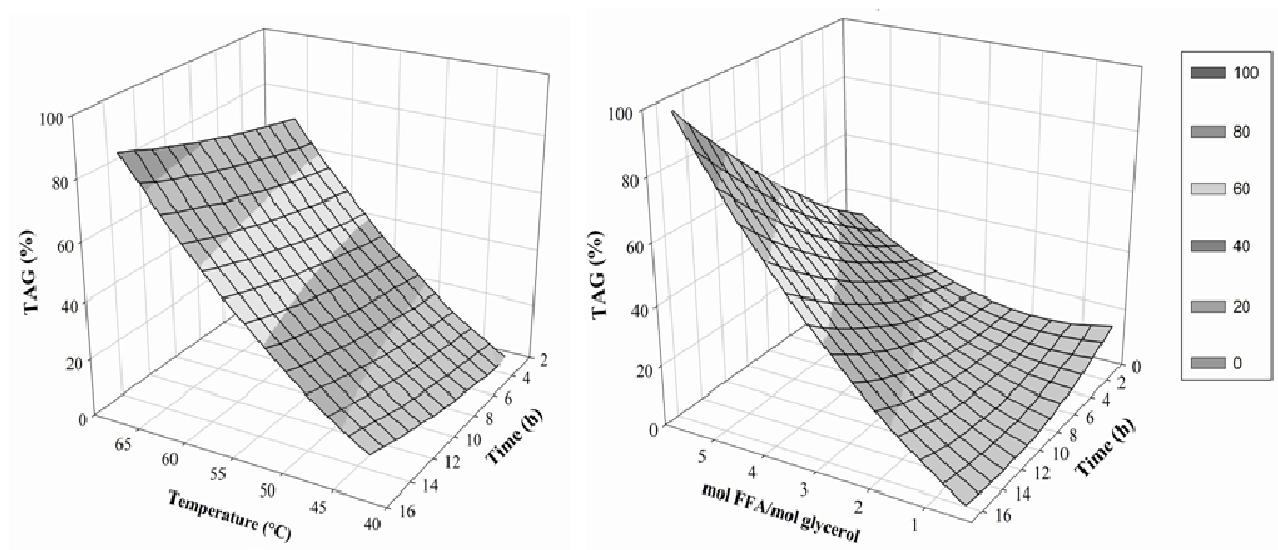

Figure 2. Response surface for TAG formation during esterification of n-3 PUFA on glycerol 


\subsection{Production of Diacylglycerols (DAG)}

We obtained $35 \%$ of DAG for a $0.48 \mathrm{FFA} /$ glycerol substrate molar ratio, after $5.75 \mathrm{~h}$ at $55{ }^{\circ} \mathrm{C}$ (experiment 9). The ANOVA proved that reaction time had a significant effect $(\mathrm{P}<0.05)$ on DAG production. The model for the production of DAG is:

$$
y_{3}=-11.7-0.027 \mathrm{x}_{1}+9.6 \mathrm{x}_{2}+0.58 \mathrm{x}_{3}-0.30 \mathrm{x}_{1}{ }^{2}-0.07 \mathrm{x}_{1} \mathrm{x}_{2}-0.46 \mathrm{x}_{2}{ }^{2}-0.05 \mathrm{x}_{1} \mathrm{x}_{3}-0.07 \mathrm{x}_{3} \mathrm{x}_{2}-0.000 \mathrm{x}_{3}{ }^{2}
$$

where $y_{3}$ is the extent of DAG production, $x_{1}$ the substrate molar ratio, $x_{2}$ the reaction time and $x_{3}$ the temperature.

Figure 3 shows a maximum DAG yield production in the middle level of the reaction time $(5.75 \mathrm{~h})$. It can also be noted that for low substrate molar ratios, higher DAG production was obtained. It has been reported that the highest level of DAG production (30-35\%) is obtained at short reaction times (Haraldsson, Gudmundson, \& Almarsson, 1995; Kosuki \& Azuma, 1994). Recent works have produced 50\% DAG by glycerolysis of oil catalyzed by lipases (Wanget al., 2011; Miranda et al., 2013).
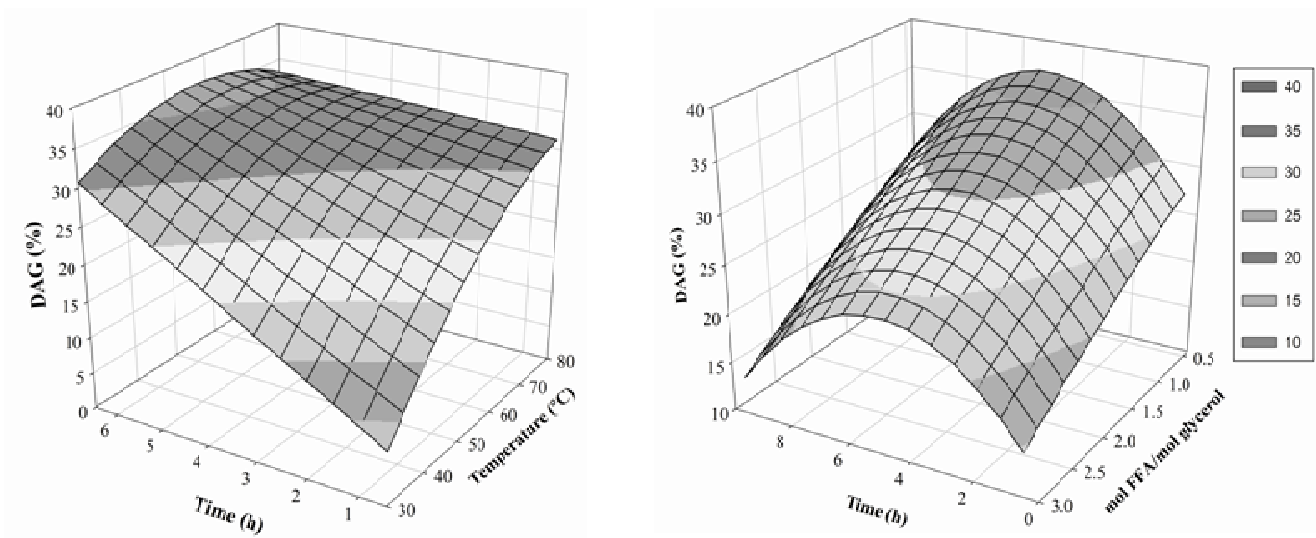

Figure 3. Response surface for DAG formation during esterification of n-3 PUFA on glycerol

\subsection{Production of Monoacylglycerols (MAG)}

The highest MAG production (58.2\%) was obtained with a $4.5 \mathrm{FFA} /$ glycerol substrate molar ratio, after $2.75 \mathrm{~h}$ at $45{ }^{\circ} \mathrm{C}$ (experiment 5). We observed a rapid MAG formation in the beginning of the reaction, but it decreased with reaction time due to the subsequent formation of DAG and TAG. The model for MAG formation is:

$$
y_{4}=152.9+0.15 \mathrm{x}_{1}+3.4 \mathrm{x}_{2}-3.9 \mathrm{x}_{3}+1.4 \mathrm{x}_{1}{ }^{2}-0.77 \mathrm{x}_{1} \mathrm{x}_{2}-0.15 \mathrm{x}_{2}^{2}-0.11 \mathrm{x}_{1} \mathrm{x}_{3}+0.001 \mathrm{x}_{3} \mathrm{x}_{2}+0.033 \mathrm{x}_{3}{ }^{2}
$$

where $y_{4}$ is the extent of MAG formation, $x_{1}$ the substrates molar ratio, $x_{2}$ the reaction time and $x_{3}$ the temperature.

Figure 4 shows that for a very short reaction time and a high substrate molar ratio, a higher amount of MAG was produced. In contrast, $\mathrm{Li}$ and Ward (1994) reported that the high production of MAG and DAG is due to the positional specificity of the lipases employed (Pseudomonas sp. and Mucor miehei). 

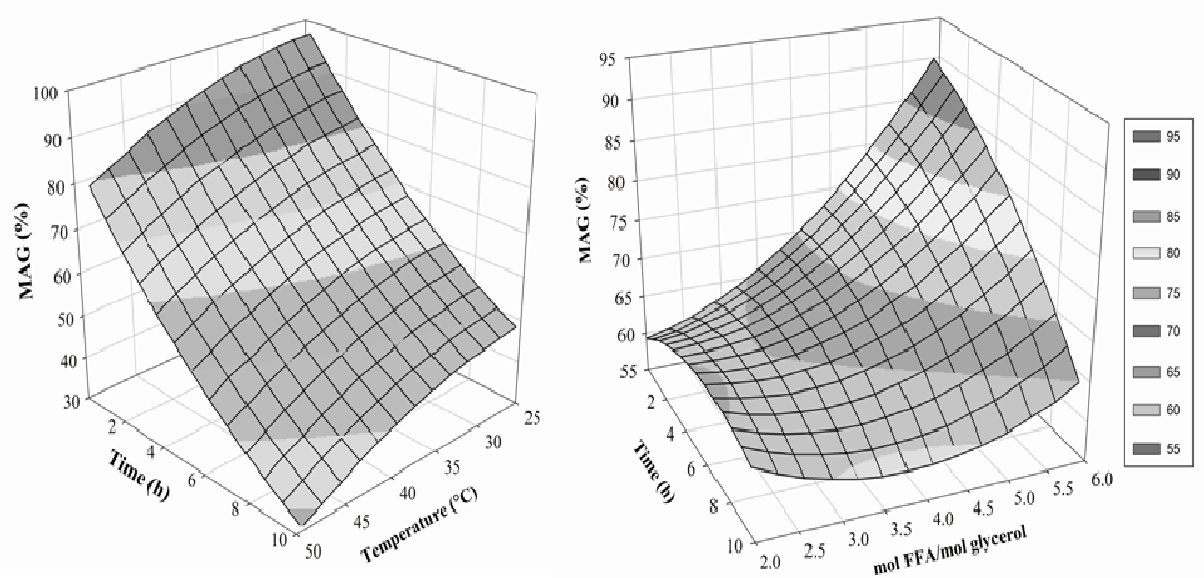

Figure 4. Response surface for MAG formation during esterification of n-3 PUFA on glycerol

\subsection{Optimal Conditions for Esterification}

Results of this work permited the correct determination of the conditions which produce a maximum yield of the desired acylglycerol as product. According to the RSM analysis, the experimental settings that produced the highest degree of esterification were within those of our experimental trials. As it is shown in Table 3, the optimal conditions for TAG formation (> 95\%) were: $4.2 \mathrm{FFA} /$ glycerol substrates molar ratio, $12 \mathrm{~h}$ and $72{ }^{\circ} \mathrm{C}$; whereas for MAG formation these conditions were rather contrasting (more than $4.2 \mathrm{FFA} / \mathrm{glycerol}$, less than 2.0 $\mathrm{h}$ and $30^{\circ} \mathrm{C}$ ). DAG production was maximized with a $1.0 \mathrm{FFA} / \mathrm{glycerol}$ substrates molar ratio, $5 \mathrm{~h}$ and $50^{\circ} \mathrm{C}$.

Table 3. Optimal conditions for the main variables of esterification

\begin{tabular}{lllll}
\hline Product & $\begin{array}{l}\text { Production } \\
(\%)\end{array}$ & $\begin{array}{l}\text { Substrate mole ratio } \\
(\mathbf{m o l} \text { FFA/mol Glycerol) }\end{array}$ & $\begin{array}{l}\text { Time } \\
(\mathbf{h})\end{array}$ & $\begin{array}{l}\text { Temperature } \\
\left({ }^{\circ} \mathbf{C}\right)\end{array}$ \\
\hline MAG & 90 & $>4.2$ & $<2.0$ & 30 \\
DAG & 45 & 1.0 & 5.0 & 50 \\
TAG & 95 & 4.2 & $>12$ & 72 \\
\hline
\end{tabular}

MAG: monoacylglycerols, DAG: diacylglycerols, TAG: triacylglycerols.

\section{Conclusion}

In the present work, we successfully estimated by RSM the production of structured acylglycerols with elevated n-3 PUFA using an immobilized lipase from Candida antarctica (NV-435). The $\mathrm{R}^{2}(>0.97)$ and ANOVA suggest that the model represented well the relationship of the main variables and the response. The variables with the highest significant effect on the extent of n-PUFA incorporation were the reaction time and the substrate molar ratio. It is possible to drive the reaction to any desired product (namely MAG, DAG or TAG) with elevated n-PUFA by modifying the reaction conditions of substrate molar ratio, temperature and time.

\section{References}

AOCS. (2009). Official methods and recommended practices of American Oil Chemists' Society (6th ed.). Champaign, IL: American Oil Chemists' Society.

Cleland, L. G., Caughey, G. E., James, M. J., \& Proudman, S. M. (2006). Reduction of cardiovascular risk factors with long term fish oil treatment in early rheumatoid arthritis. J. Rheumat., 33, 1973-1979.

Esteban, C. L., Robles, M. A., Jiménez, G. A., Ibáñez, G. M., \& Molina, G. E. (1998). Synthesis of polyunsaturated fatty acid-enriched tryglicerides by lipase-catalyzed esterification. J. Am. Oil Chem. Soc., 75(10), 1329-1337.

Gámez-Meza, N., Noriega-Rodríguez, J. A., Medina-Juárez, L. A., Ortega-García, J., Monroy-Rivera, J. A., Toro-Vázquez, F. J., ... Angulo-Guerrero, O. (2003). Concentration of eicosapentaenioc acid and docosahexaenoic acid from fish oil by hydrolysis and urea complexation. Food Res. Int., 36, 721-727. 
http://dx.doi.org/10.1016/S0963-9969(03)00052-8

Haraldsson, G. G., Gudmundson, B. O., \& Almarsson, O. (1995). The synthesis of homogeneous triglycerides of eicosapentaenoic acid and docosahexaenoic acid by lipase. Tetrahedron, 51, 941-952. http://dx.doi.org/10.1016/0040-4020(94)00983-2

Haraldsson, G. G., Kristinsson, B., Sigurdardottir, R., Gudmundsson, G. G, \& Breivik, H. (1997). The preparation of concentrates of eicosapentaenoic acid and docosahexaenoic acid by lipase-catalyzed transesterification of fish oil with ethanol. J. Am. Oil Chem. Soc, 74, 1419-1424. http://dx.doi.org/10.1007/s11746-997-0247-1

Harris, W. S., \& Isley, W. L. (2001). Clinical trial evidence for the cardioprotective effects of omega-3 fatty acids.Curr. Ather. Rep., 3, 174-179. http://dx.doi.org/10.1007/s11883-001-0055-2

Hu, F., Manson, J. E., \& Willett, W. (2001). Types of dietary fat and risk of coronary heart disease: a critical review. Am. J. Coll. Nutr., 20, 5-19. http://dx.doi.org/10.1080/07315724.2001.10719008

Kosugi, A., \& Azuma, N. (1994). Synthesis of triacylglycerol from polyunsaturated fatty acid by immobilized lipase. J. Am. Oil Chem. Soc., 71, 1397-1403. http://dx.doi.org/10.1007/BF02540528

Li, D., Bode, O., Drummond, H., \& Sinclair, A. J. (2003). Omega 3 (n-3) fatty acids, In Gunstone.Lipids for functional foods and nutraceuticals (pp. 225-262). The Oily Press Bridgwater Eng.. http://dx.doi.org/10.1533/9780857097965.225

Li, Z. L., \& Ward, O. P. (1994). Synthesis of monoglyceride containing omega-3 fatty acids by microbial lipase in organic solvent. J. Indust. Microb, 13, 49-52. http://dx.doi.org/10.1007/BF01569662

Liu, J., Lee, T., Bobik, Jr. E., Guzman-Harty, M., \& Hastilow, C. (1993). Quantitative determination of monoglycerides and diglycerides by high-performance liquid chromatography and evaporative light-scattering detection. J. Am. Oil Chem. Soc., 70(4), 343-347. http://dx.doi.org/10.1007/BF02552704

Makrides, M., Neumann, A. M., \& Gibson, A. R. (1996). In Dietary Docosahexaenoic Acid Essential for Term Infants? Lipids, 31, 115-119. http://dx.doi.org/10.1007/BF02522420

Mantzioris, E., Cleland, L. G., \& Gibson, R. A. (2000). Biochemical effects of a diet containing foods enriched with n-3 fatty acids in fish oil. Am. J. Clin. Nutr., 72, 42-48.

Mc Neill, G. P., Ackman, R. G., \& Moore, S. R. (1996). Lipase-catalyzed enrichment of long-chain polyunsaturated fatty acids. J. Am. Oil Chem. Soc., 73, 1403-1407. http://dx.doi.org/10.1007/BF02523503

Miranda, K, Baeza-Jiménez, R., Noriega-Rodríguez, J. A., Hugo, S., \& Otero, C. (2013). Optimization of structured diacylglycerols production containing w-3 fatty acids via enzyme-catalysedglycerolysis of fish oil. Eur. Food Res. Technol., 236, 435-440. http://dx.doi.org/10.1007/s00217-012-1889-2

Montgomery, D. C. (2009). Response Surface Methods and Designs. In Design and Analysis of Experiments (7th ed.) (pp. 427-510). John Wiley \& Sons.

Nettleton, J. A. (1994). Omega-3 fatty acids and health. Chapman-and Hall, New York.

Noriega Rodríguez J. A., Ortega García J., Angulo Guerrero O., García, H. S., Medina Juarez., L. A., \& Gámez-Meza, N. (2009). Oil production from sardine (Sardinops sagax caerulea). CyTA - Journal of Food, 7(3), 173-179. http://dx.doi.org/10.1080/19476330903010243

Robles, M. A., Esteban, C. L., Giménez, G. A., Camacho, P. B., Ibáñez, M. J., \& Molina, G. E. (1999). Lipase-catalyzed esterification of glycerol and polyunsaturated fatty Acids on blood lipids and platelet function in healthy volunteers. Clin. Sci., 64, 91-99.

Sellmayer, A., \& Koletzco, B. (1999). Long chain polyunsaturated fatty acids and eicosanoids in infants: Physiological and pathphysiological aspects, an open question. Lipids, 34, 199-205. http://dx.doi.org/10.1007/s11745-999-0354-z

Shimada, Y., Sugihara, A., Nakano, H., Kuramoto, T., Nagao, T., Gemba, M., \& Tominaga,Y. (1997). Purification of Docosahexaenoic Acid by Selective Esterification of Fatty Acids from Tuna Oil with Rhizopusdelemar Lipase. J. Am. Oil Chem. Soc., 74, 97-101. http://dx.doi.org/10.1007/s11746-997-0151-8

Simopoulos, A. P. (2002). Omega-3 fatty acids in inflammation and autoimmune diseases. J. Am. Coll. Nutr, 21, 495-505. http://dx.doi.org/10.1080/07315724.2002.10719248

Valenzuela, A., Valenzuela,V., Sanhueza, J., \& Nieto, S. (2005). Effect of supplementation with docosahexaenoic acid ethyl ester and sn-2 docosahexaenyl monoacylglyceride on plasma and erythrocyte fatty acids in rats. 
Ann. Nutr. Metab., 49, 49-53. http://dx.doi.org/10.1159/000084177

Von Schacky, C. (2007). N-3 PUFA in CVD: influence of cytokine polymorphism. Proc. Nutr. Soc., 66, 166-170. http://dx.doi.org/10.1017/S0029665107005411

Wang, W., Li, T., Ning, Z., Wang, Y., Yang, B., \& Yang, X. (2011). Production of extremely pure diacylglycerol from soybean oil by lipase-catalyzed glycerolysis. Enzyme Microb. Tech., 49, 192-196. http://dx.doi.org/10.1016/j.enzmictec.2011.05.001

Young, J. (2003). Introduction. In Lipids for Functional Foods and Nutraceuticals, In D. G. Frank (Ed.) (pp. 1-23). The Oily Press, Bridgwater Eng. http://dx.doi.org/10.1533/9780857097965.1

Zhang, W., Long, Y., Zhang, J., \& Wang, C. (2007). Modulatory effects ofEPA and DHA on proliferation and apoptosis of pancreatic cancer cells. J Huazhong UnivSci Technol, 27, 547-550. http://dx.doi.org/10.1007/s11596-007-0518-y

\section{Copyrights}

Copyright for this article is retained by the author(s), with first publication rights granted to the journal.

This is an open-access article distributed under the terms and conditions of the Creative Commons Attribution license (http://creativecommons.org/licenses/by/3.0/). 